引用格式: 吴思, 胡守庚, 熊婷, 等. 长江中游经济带主体功能区土地利用转型模式研究[J]. 资源科学, 2018,40(11):2213-2224. [Wu S, Hu S G, Xiong T, et al. The pattern of land use transition in different major function zones in the Middle Reaches of Yangtze River Economic Belt[J]. Resources Science, 2018,40(11):2213-2224.] DOI :10.18402/resci.2018.11.08

\title{
长江中游经济带主体功能区土地利用 转型模式研究
}

\author{
吴 思 ${ }^{1,2}$, 胡守庚 ${ }^{1,2}$, 熊 婷 ${ }^{1,2}$, 邹谢华 ${ }^{2,3}$, 朱 繁 2,3
}

(1. 中国地质大学(武汉)公共管理学院, 武汉 430074;

2. 国土资源部法律评价工程重点实验室,武汉 430074;

3. 国土资源部不动产登记中心, 北京 100034)

\begin{abstract}
摘 要: 在国家深入推进生态文明建设和实施主体功能区战略的背景下, 区域土地利用转型模式设计对缓解 快速城镇化过程中社会经济发展与上地利用之间的矛盾具有重要意义。本文选取长江中游经济带为研究区,以 325 个县 (区) 作为基本研究单元, 采用遥感和社会经济等数据, 从土地利用形态(显性/隐性)转换的视角构建以耕 地、建设用地和林地为典型地类的转型模式要素体系, 并在此基础上解析新时期新目标对土地利用转型的要求, 甄 别不同类型土地利用转型方向, 进而遵循可持续发展和主导性原则, 总结归纳不同主体功能区土地利用转型模 式。研究结果表明: 长江中游经济带城市化地区土地利用转型模式包括规模与产出能力适度提升型 $\left(D_{u}+R_{u}+\right.$ 主导 型)、规模控制而产出能力适度提升型 $\left(D_{u} R_{u}+\right.$ 主导型 $)$ 等四种; 农产品主产区转型模式包括规模和产出能力稳定型 $\left(D_{c} R_{c}\right.$ 主导型) 、规模稳定而产出能力提升型 $\left(D_{c} R_{c}+\right.$ 主导型 $)$ 等四种; 重点生态功能区转型模式包括规模增加型 $\left(D_{f}+\right.$ 主导型) 和规模稳定型 $\left(D_{f}\right.$ 主导型) 两种。模式研究有望能为进一步推动长江中游经济带各主体功能区城乡融合发 展和促进各县(区) 土地可持续利用提供参考。
\end{abstract}

关键词: 土地利用转型; 模式; 主体功能区; 长江中游经济带

DOI :10.18402/resci.2018.11.08

\section{1 引言}

改革开放以来, 中国经济实力迅速增长, 然而部 分地区为追求经济发展,往往忽略了自身资源禀赋, 导致国土空间开发无序、区域发展不平衡等问题突 出, 国家粮食安全和生态安全也受到了极大威胁 ${ }^{[1]}$ 。 如何有效破解这些现实发展难题以实现土地可持 续利用, 已成为寻求区域社会经济生态协调发展的 内在要求。与此同时, 中国正处于社会经济转型的 关键时期, 土地作为承载人类主要社会经济活动的 载体也随之发生着剧烈转型。在此背景下, 土地利用 转型研究已逐渐成为各界均广泛关注的重要课题。
土地利用转型作为土地利用/覆被变化(LUCC) 综合研究的新途径,其核心目标是通过管理好利用 好土地资源进而促进区域经济社会的可持续发展， 实则是在经济社会变化和革新的驱动下,一段时期 内与经济和社会发展阶段转型相对应的区域土地 利用形态转变的过程 ${ }^{[2]}$ 。其中土地利用形态包括数 量、空间结构等显性形态以及质量、产权、经营方式等 隐性形态 ${ }^{[2-5]}$ 。土地利用转型最早是由英国 Grainger 在研究国家土地利用时所提出 ${ }^{[6]}$, 随后龙花楼等 ${ }^{[7,8]}$ 将这一研究理念引人国内, 自此国内学者从概念与 内涵 ${ }^{[2,3]}$ 、理论与假说 ${ }^{[9-11]}$ 、特征刻画 ${ }^{[12-23]}$ 、效应测度 ${ }^{[24-29]} 、$ 


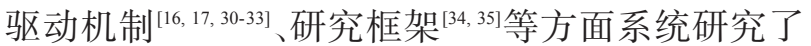
土地利用转型的基本内容与方法体系, 同时也开展 了土地利用转型与土地资源管理、乡村转型发展等 之间的联系 ${ }^{[2,3,36]}$ 以及不同类型土地利用转型关系 ${ }^{[37]}$ 等方面的研究。综合来看, 上述研究多关注对过去 一段时间土地利用转型的 “描述与解释”, 较少从实 际发展需求出发探寻未来区域土地利用转型目标、 途径、方向和模式。不同社会经济发展阶段对应于 不同区域土地利用形态转型阶段, 必然会带来特定 土地利用转型过程。因此, 如何在综合分析社会经 济发展需求的基础上开展土地利用转型模式研究, 不仅是未来增强土地利用转型对现实的解释力、丰 富土地利用转型研究领域的必然要求, 更是充分发 挥土地资源优势实现社会经济转型的关键。同时， 随着中国土地管理方式由单纯以数量为主逐渐转 向综合管理,开展土地利用显性和隐性形态综合研 究已成为深层次认识土地利用转型内涵、完善土地 利用管理方式的必然选择 ${ }^{[1]}$ 。然而已有研究多聚焦 于单一土地类型利用的显性形态 (以建设用地和耕 地为主), 综合多类型土地利用显性和隐性形态研 究相对薄弱, 已有研究成果对区域土地可持续利用 的实际指导意义受限。此外, 中长期发展目标的主 体功能区规划明确提出不同主体功能区的范围、功 能定位、发展目标、区域政策等, 其核心是通过国土 空间分类开发来推动区域协调发展, 而这很大程度上 需要通过土地资源的合理配置与利用来实现 ${ }^{[38-40]}$ 。 从这个意义上来看, 土地利用转型与主体功能区划 密不可分, 而土地利用转型模式设计应以主体功能 区格局为前提和基础。

因此, 本文以 2015 年为研究基期, 在剖析社会 经济发展等多重目标对长江中游经济带各县 (区) 土地利用转型要求的基础上,遵循可持续发展和主 导性原则, 提出新形势新发展背景下不同主体功能 区所需的区域土地利用形态发生转变的典型形式, 即土地利用转型模式。

\section{2 研究区概况与数据来源}

\section{1 研究区概况}

长江中游经济带包括湖北、湖南和江西三省, 东邻皖浙闽, 南毗两广, 西接渝黔, 北连陕豫, 地跨 东经 $108^{\circ} 21^{\prime} \mathrm{E}-118^{\circ} 28^{\prime} \mathrm{E}$, 北纬 $20^{\circ} 09^{\prime} \mathrm{N}-33^{\circ} 20^{\prime} \mathrm{N}$,
国土总面积为 56.47 万 $\mathrm{km}^{2}$, 约占全国陆地面积的 $5.88 \%$ (图 1)。

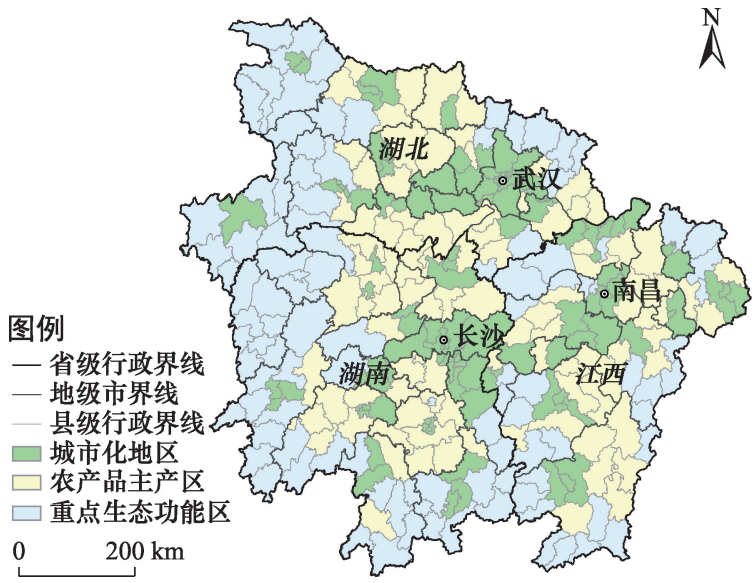

图 1 长江中游经济带区位及其主体功能区分布

Figure 1 Location of the Middle Reaches of Yangtze River Economic Belt and distribution of its major function zones

长江中游经济带位于全国“两横三纵”城市化 战略格局中沿长江通道横轴和京哈京广通道纵轴 的交汇处,随着“一带一路”倡议以及“中部崛起” “长江经济带”等国家重点战略的提出, 长江中游经 济带发展不断提速,已成为中国经济发展的重要增 长极 ${ }^{[41]}$ 。全国 “七区二十三带”农业战略格局 ${ }^{[2]}$ 的长 江流域主产区主要分布于此, 《全国生态功能规划》|[43] 所确定的 63 个生态功能区中有 12 个或部分或全部 位于该区域。因此,如何充分发挥土地资源优势, 处理好经济发展、粮食生产、生态保护等发展目标 与土地利用之间的关系将成为未来长江中游经济 带健康、和谐、可持续发展的重要一环。

\section{2 数据来源}

采用的社会经济数据主要来源于 2016 年《中国

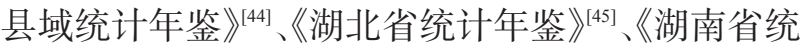
计年鉴》 ${ }^{[46]}$ 和《江西省统计年鉴》 ${ }^{[47]}$, 部分来源于各市 或县统计年鉴 ${ }^{[48]}$ 。采用的土地利用数据来源于中国 科学院资源环境科学数据中心 ${ }^{[49]}$, 以 Landsat 影像为 数据源, 并参照国家基本资源与环境本底动态遥感 调查数据库的分类体系, 将土地利用类型分为耕地、 林地、草地、水域、建设用地和未利用地 6 个大类。

\section{3 土地利用转型模式划分}

\section{1 模式划分思路}

研究围绕“构建转型模式要素体系-确定转型 
目标-甄别转型方向-归纳转型模式”的思路展开长 江中游经济带各主体功能区土地利用转型模式的划 分。首先, 基于土地利用转型研究理论, 从土地利用 类型和土地利用形态两方面, 结合研究区资源禀赋和 社会经济状况,诊断转型模式设计的核心要素及表征 指标, 构建土地利用转型模式要素体系。其次, 在 解析不同发展规划对长江中游经济带各县 (区) 社 会经济发展和土地利用要求的基础上,匹配土地利用 转型目标与土地利用现状, 甄别不同类型土地利用 转型方向。在此基础上,遵循可持续发展原则和主 导性原则, 充分考虑各主体功能区的功能定位, 提 炼差别化的主体功能区土地利用转型模式(图 2)。

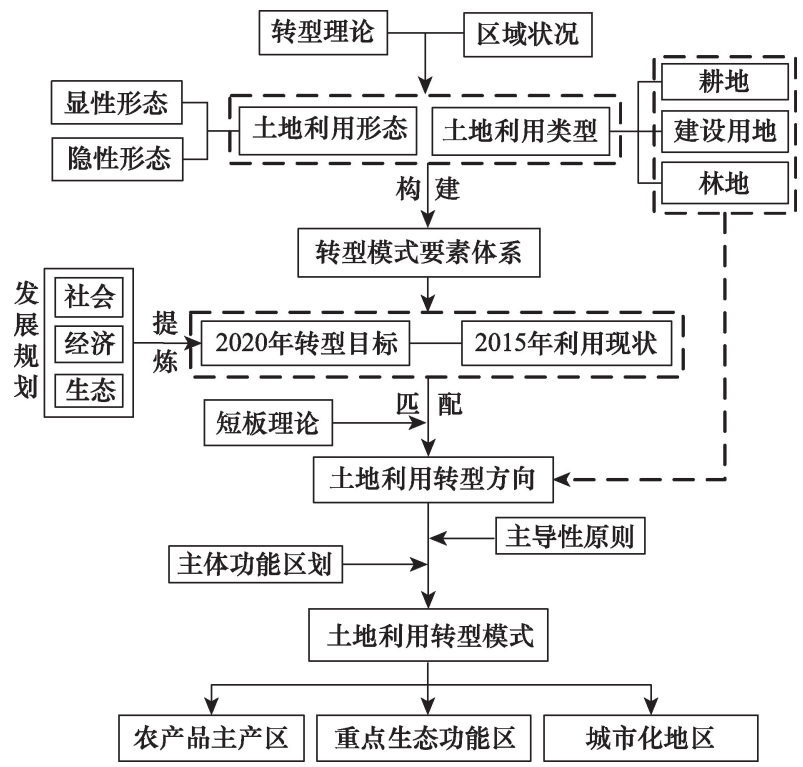

图 2 土地利用转型模式设计流程

Figure 2 Design route of the patterns of land use transition

\section{2 转型模式要素体系构建}

土地利用转型服务于社会经济转型发展, 长江中 游经济带正处于快速城镇化进程中,随着生态文明建 设战略的不断推进，如何合理配置和协调利用好各
类用地实现社会经济生态协调发展日益重要,矛盾 焦点主要集中在建设用地、耕地以及生态用地。需 要指出的是, 从当前研究中获知生态用地主要包括 林地、草地、湿地等 ${ }^{[50]}$, 鉴于研究区林地所占比例高 达 $58.06 \%$, 故而本研究选取耕地、建设用地以及林 地作为关键要素纳人土地利用转型模式要素体系。

区域土地利用转型实际上是不同类型土地利 用显性/隐性形态变化的综合体现。显性形态表现 形式主要包括数量、空间结构等,而从土地利用角 度来看,数量为最重要的显性形态表现形式, 因此 本研究选择土地规模这一指标来表征显性形态。 隐性形态包括权属、质量、投人、产出等,鉴于本文 土地利用转型模式内涵、设计目的及数据的可获取 性,研究从土地产出角度䇥选能表征不同类型土地 利用隐性形态的指标。对于长江中游经济带发展 而言, 耕地首要功能是保障粮食安全, 而建设用地 作为人类经济社会活动发生的载体, 最主要的功能 则是保障经济发展,故而分别选择粮食单产和地均 生产总值表征耕地和建设用地利用的隐性形态。 值得注意的是, 林地作为重要的生态用地, 短时间 内其生态功能具有相对稳定性, 因此在构建土地利 用转型模式要素体系时,暂不考虑林地利用隐性形 态。综上,本文从土地利用显性/隐性形态出发, 构 建以耕地、建设用地和林地为代表的土地利用转型 模式要素体系(表1)。

\section{3 转型方向划分}

（1）建设用地利用转型方向。基于构建的土地 利用转型模式要素体系, 建设用地利用转型方向由 显性形态(数量)和隐性形态(产出)的转型方向共 同决定。鉴于短期内土地利用转型主要受社会经 济发展影响,而土地利用总体规划(简称“规划”)中 土地利用目标是基于社会经济发展需求提出的,因

表 1 土地利用转型模式要素体系

Table 1 The index system of land use transition patterns

\begin{tabular}{|c|c|c|c|}
\hline 土地利用类型 & 土地利用形态(变量) & 表征因素 & 度量指标/单位 \\
\hline \multirow[t]{2}{*}{ 建设用地 } & 显性形态 $\left(D_{u}\right)$ & 建设用地数量 & 建设用地规模/hm² \\
\hline & 隐性形态 $\left(R_{u}\right)$ & 建设用地产出 & 地均生产总值 $/\left(\right.$ 亿元 $\left./ \mathrm{hm}^{2}\right)$ \\
\hline \multirow[t]{2}{*}{ 耕地 } & 显性形态 $\left(D_{c}\right)$ & 耕地数量 & 耕地规模 $/ \mathrm{hm}^{2}$ \\
\hline & 隐性形态 $\left(R_{c}\right)$ & 耕地产出 & 粮食单产/(t/hm²) \\
\hline 林地 & 显性形态 $\left(D_{f}\right)$ & 林地数量 & 林地规模/hm² \\
\hline
\end{tabular}


此本研究以长江中游经济带各市、县 (区) 规划中的 2020 年建设用地预期规模作为建设用地利用显性 形态的发展目标。地均生产总值作为表征隐性形 态(建设用地产出)的综合性指标,与各地区的经济 发展水平、建设用地数量状况等紧密有关。为更准 确地把握建设用地利用隐性形态的转型方向, 本文 参考刘琼等人的研究 ${ }^{[1]}$, 基于 2015 年各县(区)的地 区生产总值, 按各市或县 (区) 中“十三五规划”设定 的经济增速作为各县 (区) 2020 年地区生产总值的 发展目标,并在此基础上结合 2020 年建设用地预期 规模, 最终确定各县(区)建设用地利用转型方向。

遵循十九大提倡的长江经济带以保护为主的 发展理念,建设用地利用显性形态的转型方向以控 制建设用地规模为准则, 隐性形态的转型方向以提 高地均生产总值为准则。具体如下所示:

$$
\begin{aligned}
& \Delta D_{u}=D_{u 2020}-D_{u 2015} \\
& \Delta R_{u}=R_{u 2020}-R_{u 2015}
\end{aligned}
$$

式中, $D_{u 2220}$ 为 2020 年建设用地预期规模 $\left(\mathrm{hm}^{2}\right) ; D_{u 2015}$ 为 2015 年建设用地规模 $\left(\mathrm{hm}^{2}\right) ; R_{u 2202}$ 为 2020 年地均 生产总值预期值 $\left(\right.$ 亿元 $\left./ \mathrm{hm}^{2}\right) ; R_{u 2015}$ 为 2015 年地均生 产总值 (亿元 $\left./ \mathrm{hm}^{2}\right)$ 。

根据 $\Delta D_{u}$ 的取值范围, 建设用地利用显性形态 的转型方向可分为适度增加规模 $\left(\Delta D_{u}>0\right)$ 和控制规 模 $\left(\Delta D_{u}<0\right)$ 。根据 $\Delta R_{u}$ 的取值范围, 基于自然断点 法, 建设用地利用隐性形态的转型方向可分为适度 提升产出能力 $\left(0<\Delta R_{u} \leqslant 9.93\right)$ 和重点提升产出能力 $\left(9.93<\Delta R_{u} \leqslant 58.47\right)$ 。

综合考虑显性形态以及隐性形态的转型方向, 建设用地利用转型方向可划分为 $D_{u}+R_{u}+、 D_{u}+R_{u}++$ 、 $D_{u} R_{u}+、 D_{u} R_{u}++$ 四种 (图 3)。其中 $D_{u}+R_{u}+$ 表示转型方 向为适度增加规模并适度提升产出能力 $\left(\Delta D_{u}>0\right.$ 且 $\left.0<\Delta R_{u} \leqslant 9.93\right), D_{u}+R_{u}++$ 表示转型方向为适度增加规 模并重点提升产出能力 $\left(\Delta D_{u}>0\right.$ 且 $9.93<\Delta R_{u} \leqslant$ $58.47), D_{u} R_{u}+$ 表示转型方向为控制规模并适度提升 产出能力 $\left(\Delta D_{u}<0\right.$ 且 $\left.0<\Delta R_{u} \leqslant 9.93\right), D_{u} R_{u}++$ 表示转型 方向为控制规模并重点提升产出能力 $\left(\Delta D_{u}<0\right.$ 且 $\left.9.93<\Delta R_{u} \leqslant 58.47\right)$ 。

(2)耕地利用转型方向。与建设用地利用转型 目标的确定思路类似, 本文以研究区各市、县 (区) 土地利用总体规划提出的 2020 年耕地保有量作为

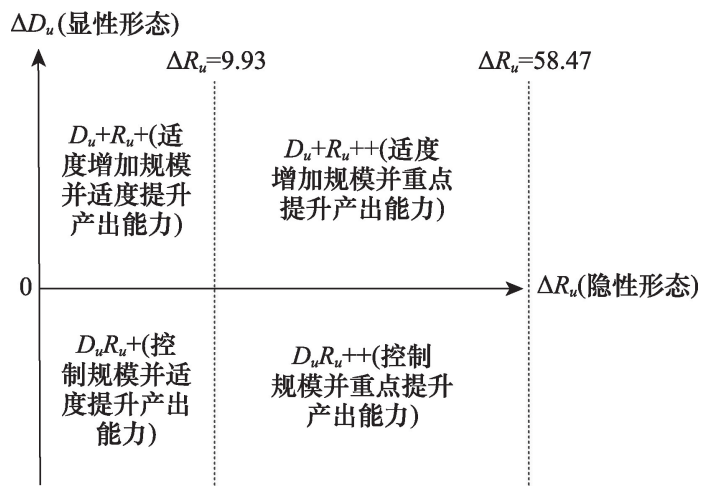

图 3 建设用地利用转型方向示意

Figure 3 The diagram of the direction of construction land use transition

各县 (区) 耕地利用显性形态转型的基本发展目 标。此外,鉴于当前中国正处于农业迈向现代化发 展的新阶段, 而长江中游经济带作为中国重要的粮 食主产区,承担着率先实现农业现代化的重任,因 此以全国农业现代化规划(2016-2020 年 ${ }^{[52]}$ 中提 倡的粮食单产 $6.5 \mathrm{t} / \mathrm{hm}^{2}$ 作为研究区耕地利用隐性形 态转型发展目标具有一定的实际意义。

结合 2015 年各县 (区) 耕地利用现状及转型发 展目标, 确定耕地利用显性形态以及隐性形态的转 型方向,具体判断方向如下:

$$
\begin{aligned}
& \Delta D_{c}=D_{c 22020}-D_{c 2015} \\
& \Delta R_{c}=R_{c 2020}-R_{c 2015}
\end{aligned}
$$

式中 $D_{c 2020}$ 为 2020 年耕地保有量预期值 $\left(\mathrm{hm}^{2}\right) ; D_{c 2015}$ 为 2015 年耕地规模 $\left(\mathrm{hm}^{2}\right) ; R_{c 2202}$ 为农业现代化粮食 单产 $\left(6.5 \mathrm{t} / \mathrm{hm}^{2}\right) ; R_{c 2015}$ 为 2015 年粮食单产 $\left(\mathrm{t} / \mathrm{hm}^{2}\right)$ 。

遵循耕地保护的基本原则, 按照 $\Delta D_{c}$ 和 $\Delta R_{c}$ 的取 值范围,耕地利用显性形态转型方向包括稳定规模 $\left(\Delta D_{c}<0\right)$ 和扩大规模 $\left(\Delta D_{c}>0\right)$ 两种, 隐性形态转型方 向包括稳定粮食单产 $\left(\Delta R_{c}<0\right)$ 和提高粮食单产 $\left(\Delta R_{c}>0\right)$ 两种。

综合两种利用形态的转型方向,基于短板理 论, 耕地利用转型方向可分为 $D_{c}+R_{c} 、 D_{c}+R_{c}+、 D_{c} R_{c}$ 和 $D_{c} R_{c}+$ 这四种 (图 4)。其中 $D_{c}+R_{c}$ 表示转型方向为扩 大规模 $\left(\Delta D_{c}>0\right.$ 且 $\left.\Delta R_{c}<0\right), D_{c}+R_{c}+$ 表示转型方向为扩 大规模并提高产出能力 $\left(\Delta D_{c}>0\right.$ 且 $\left.\Delta R_{c}>0\right), D_{c} R_{c}$ 表示 转型方向为稳定规模 $\left(\Delta D_{c}<0\right.$ 且 $\left.\Delta R_{c}<0\right), D_{c} R_{c}+$ 表示 转型方向为稳定规模并提高产出能力 $\left(\Delta D_{c}<0\right.$ 且 $\left.\Delta R_{c}>0\right)$ 。 


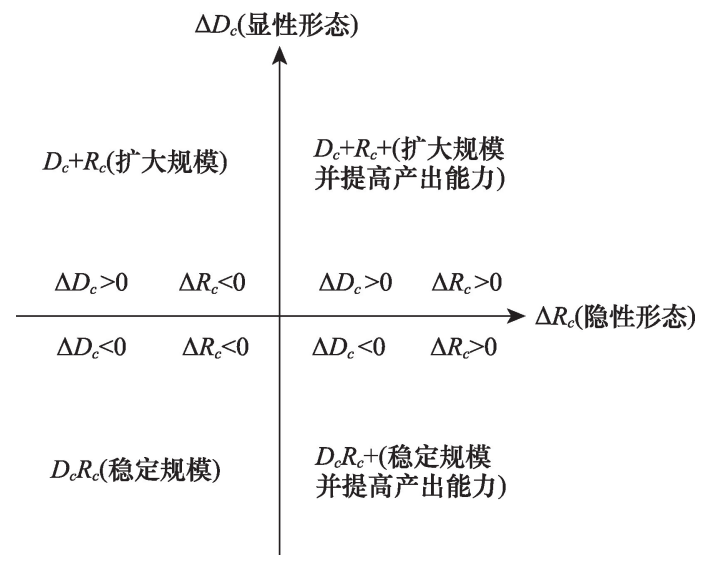

图 4 耕地利用转型方向示意

Figure 4 The diagram of the direction of cultivated land use transition

(3)林地利用转型方向。林地利用转型方向由 其显性形态转型方向决定,具体划分思路与耕地和 建设用地的划分思路一致, 即通过对比林地的现状 值与目标值,判断林地利用转型方向。若2015年某 地区的林地规模小于 2020 年林地预期规模, 则其林 地利用转型方向为 $D_{f}+$ (扩大规模) ; 反之, 则为 $D_{f}$ (稳定规模)。

\section{4 转型模式划分}

土地利用转型模式即为土地利用形态按照发 展目标发生转变的典型形式。按照主体功能区规 划对不同主体功能区功能定位、发展目标等的要 求,不同主体功能区土地利用转型路径存在明显差 异性。因此,本文主要是在充分考虑不同类型土地
利用转型方向的基础上,遵循主导性原则,归纳提 炼出不同主体功能区的土地利用转型模式。

主体功能区规划明确指出,城市化地区作为重 点进行工业化和城镇化开发的地区, 应以提供工业 品和服务产品为主, 但也提供农产品和生态产品 ${ }^{[42]}$ 。由此可知,城市化地区土地利用转型方向应以 建设用地利用转型方向为主,耕地和林地利用转型 方向为辅。据此,城市化地区土地利用转型模式可 归纳为以下四种: $D_{u}+R_{u}+$ 主导型、 $D_{u}+R_{u}++$ 主导型、 $D_{u} R_{u}+$ 主导型、 $D_{u} R_{u}++$ 主导型 (表 2 )。其中 $D_{u}+R_{u}+$ 主 导型地区应在释放其建设用地规模潜力的同时,适 度提升建设用地产出能力; $D_{u}+R_{u}++$ 主导型地区应 在释放其建设用地规模潜力的同时,重点提升建设 用地产出能力; $D_{u} R_{u}+$ 主导型地区应进一步控制建设 用地规模, 并适度提升建设用地产出能力; $D_{u} R_{u}++$ 主导型地区应在控制建设用地规模的同时,重点提 升建设用地产出能力。

农产品主产区作为保障粮食供给和粮食安全 的关键区域,按主体功能区规划要求,未来发展中 应尽量减少大规模的开发, 以提供农产品为主要功 能, 但也提供生态产品、服务产品和工艺品 ${ }^{[42]}$ 。可 见,农产品主产区土地利用转型方向应以耕地利用 转型方向为主,建设用地和林地利用转型方向为辅 助。据此,农产品主产区土地利用转型模式应包括 $D_{c}+R_{c}$ 主导型 $、 D_{c}+R_{c}+$ 主导型、 $D_{c} R_{c}$ 主导型和 $D_{c} R_{c}+$ 主

表 2 不同主体功能区土地利用转型模式

Table 2 The patterns of land use transition in different major function zones

\begin{tabular}{|c|c|c|c|}
\hline 主体功能区 & 模式划分思路 & 土地利用转型模式 & 模式说明 \\
\hline \multirow[t]{4}{*}{ 城市化地区 } & \multirow{4}{*}{$\begin{array}{l}\text { 建设用地利用转型方向 } \\
\text { 为主导, 耕地/林地利用 } \\
\text { 转型方向为辅助 }\end{array}$} & $D_{u}+R_{u}+$ 主导型 & $\begin{array}{l}\text { 建设用地规模与产出能力需适度提升, 其中建设用地产出能力提 } \\
\text { 升范围在 }(0 \sim 9.93) \text { 亿元 } / \mathrm{hm}^{2} \text { 之间 }\end{array}$ \\
\hline & & $D_{u}+R_{u}++$ 主导型 & $\begin{array}{l}\text { 建设用地规模需适度增加, 建设用地产出能力需大幅提升, 提升范 } \\
\text { 围在(9.94 58.47) 亿元 } / \mathrm{hm}^{2} \text { 之间 }\end{array}$ \\
\hline & & $D_{u} R_{u}+$ 主导型 & $\begin{array}{l}\text { 建设用地规模需进一步控制, 建设用地产出能力需适度提升, 提升 } \\
\text { 范围在(0 } 9.93) \text { 亿元 } / \mathrm{hm}^{2} \text { 之间 }\end{array}$ \\
\hline & & $D_{u} R_{u}++$ 主导型 & $\begin{array}{l}\text { 建设用地规模需进一步控制, 建设用地产出能力需大幅提升, 提升 } \\
\text { 范围在(9.94 58.47) 亿元 } / \mathrm{hm}^{2} \text { 之间 }\end{array}$ \\
\hline \multirow[t]{4}{*}{ 农产品主产区 } & \multirow{4}{*}{$\begin{array}{l}\text { 耕地利用转型方向为主 } \\
\text { 导, 建设用地/林地利用 } \\
\text { 转型方向为辅助 }\end{array}$} & $D_{c}+R_{c}$ 主导型 & 耕地规模适度增加, 耕地产出能力需保持稳定 \\
\hline & & $D_{c}+R_{\mathrm{c}}+$ 主导型 & 耕地规模适度增加,耕地产出能力需提升至 $6.5 \mathrm{t} / \mathrm{hm}^{2}$ \\
\hline & & $D_{c} R_{c}$ 主导型 & 耕地规模和耕地产出能力需保持稳定 \\
\hline & & $D_{c} R_{c}+$ 主导型 & 耕地规模稳定,耕地产出能力需提升至 $6.5 \mathrm{t} / \mathrm{hm}^{2}$ \\
\hline \multirow[t]{2}{*}{ 重点生态功能区 } & \multirow{2}{*}{$\begin{array}{l}\text { 林地利用转型方向为主 } \\
\text { 导, 耕地/建设用地利用 } \\
\text { 转型方向为辅助 }\end{array}$} & $D_{f}+$ 主导型 & 林地规模适度增加 \\
\hline & & $D_{f}$ 主导型 & 林地规模需保证不减少 \\
\hline
\end{tabular}


导型 (表 2)。其中 $D_{c}+R_{c}$ 主导型地区在适度增加耕 地规模的同时, 应保持或提升其粮食单产; $D_{c}+R_{c}+$ 主 导型地区在适度增加耕地规模时, 应重点提升粮食 单产使其达到农业现代化标准; $D_{c} R_{c}$ 主导型地区应 注重稳定耕地规模和粮食单产; $D_{c} R_{c}+$ 主导型地区应 以提升粮食单产为重任,稳定耕地规模。

重点生态功能区作为重要的生态保障, 按主体 功能区规划的要求, 应以增强生态产品生产能力为 主要任务, 限制大规模高强度的开发 ${ }^{[22]}$ 。可见, 重点 生态功能区土地利用转型方向应以林地利用转型 方向为主, 耕地和建设用地利用转型方向为辅。按 照上述划分思路, 重点生态功能区土地利用转型模 式可归纳为 $D_{f}+$ 主导型和 $D_{f}$ 主导型这两种 (表 2)。 其中 $D_{f}+$ 主导型地区应在保护林地的同时, 通过植 树造林等工程增加林地规模, 提升森林覆盖率以达 到预期目标; $D_{f}$ 主导型地区应重点防止毁林开荒等 行为, 保持森林覆盖率。

\section{4 模式划分结果}

(1)城市化地区土地利用转型模式。长江中游 经济带城市化地区土地利用转型模式包括 $D_{u} R_{u}+$ 主 导型、 $D_{u}+R_{u}+$ 主导型、 $D_{u} R_{u}++$ 主导型和 $D_{u}+R_{u}++$ 主导 型四种, 其县 (区) 数量分别为 $69 、 27 、 20$ 和 6 个。从 其空间分布上来看, $D_{u} R_{u}+$ 主导型广泛分布于湖北和 江西; $D_{u}+R_{u}+$ 主导型零散分布于武汉、天门、潜江、
南昌、宜春等市; $D_{u} R_{u}++$ 主导型主要分布于长沙、岳 阳、怀化、邵阳、永州、椰州等市中经济发展基础较 好且城市规模相对较大的县 (区) ; $D_{u}+R_{u}++$ 主导型 主要分布于长沙、常德和株洲三市中, 具体包括芙 蓉区、雨花区、天心区、武陵区和芦淞区,且这些地 区发展基础较好、城市规模较小(图 5a)。需要指出 的是, 省际土地利用转型模式差异明显, 湖北和江 西均以 $D_{u} R_{u}+$ 主导型和 $D_{u}+R_{u}+$ 主导型为主, 湖南以 $D_{u} R_{u}+$ 主导型和 $D_{u} R_{u}++$ 主导型为主。可见，如何在 框定建设用地总量的前提下充分挖掘建设用地的 内部潜力、提升建设用地利用效率将是未来长江中 游经济带城市化地区发展的关键一环。

长江中游经济带城市化地区耕地利用转型方 向包括 $D_{c}+R_{c} 、 D_{c}+R_{c}+、 D_{c} R_{c} 、 D_{c} R_{c}+$ 四种类型, 其中耕 地利用转型方向为 $D_{c}+R_{c}$ 的城市化地区主要集中于 长沙、株洲、潜江、仙桃、襄阳、宜春等市，而转型方 向为 $D_{c}+R_{c}+$ 的城市化地区主要集中连片分布于武 汉及其周边城市; $D_{c} R_{c}+$ 和 $D_{c} R_{c}$ 分布相对零散, 前者 分布于岳阳、娄底、湘州、吉安、上饶等的县 (区) , 后 者分布于南昌、抚州、株洲、萍乡、永州等市的部分 县区(图 5b)。可见,长江中游经济带城市化地区面 临着全面、适度补充耕地的任务。同时值得关注的 是武汉及其周边地区的耕地规模与单产“双低”问 题突出,其可能原因是随着武汉城市圈建设的推

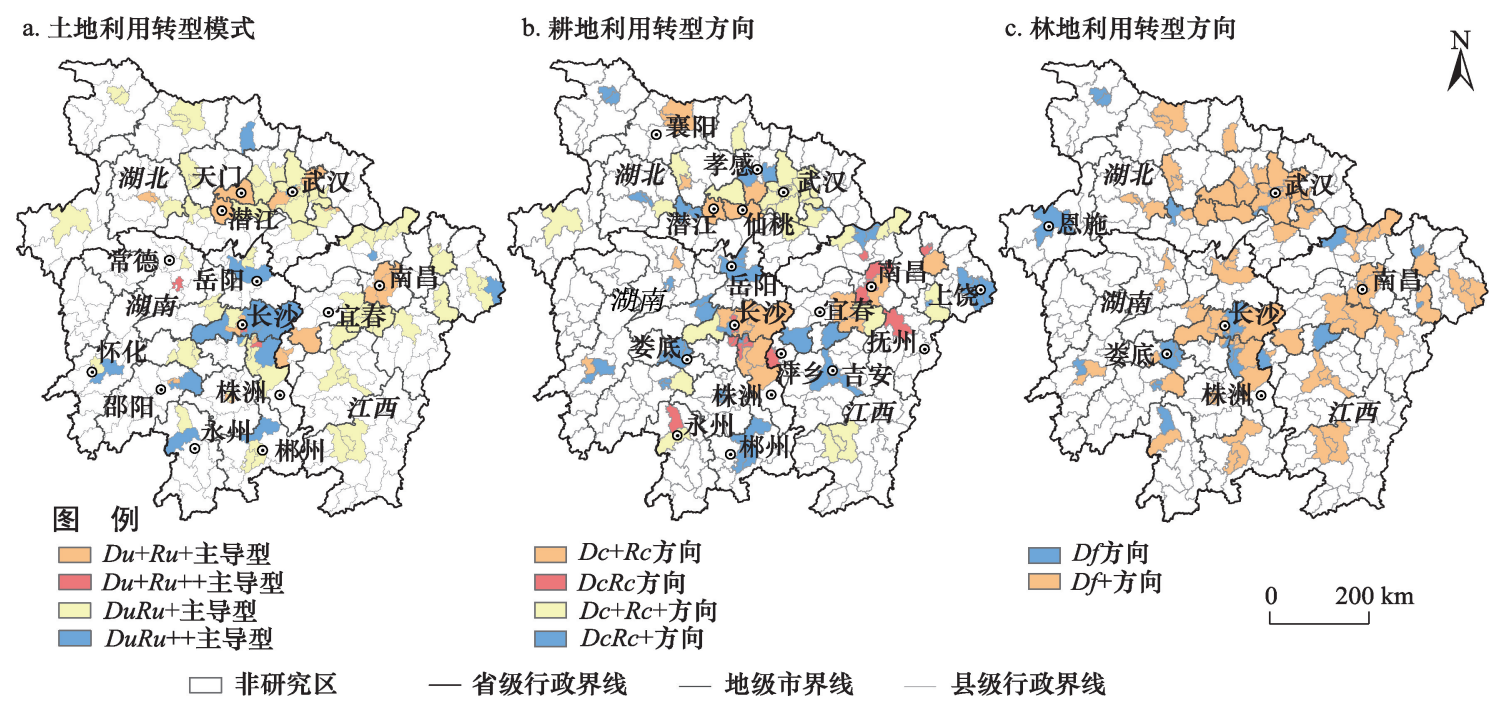

图 5 长江中游经济带城市化地区土地利用转型模式及耕地和林地利用转型方向

Figure 5 The patterns of land use transition and direction of cultivated land and forest land use transition in the urbanized zone in the Middle Reaches of Yangtze River Economic Belt 
进,武汉及其周边城市建设用地扩张明显, 破坏了 原有耕地经营格局,从而对耕地规模与粮食单产能力 产生了一定影响。此外,长江中游经济带大部分城市 化地区林地利用转型方向以 $D_{f}+$ 方向为主 (图 5c), 仅恩施、长沙、娄底、株洲等市的部分地区转型方向 为 $D_{f}+$, 这与长江中游经济带作为中国重要的生态 屏障有着密切联系。

(2)农产品主产区土地利用转型模式。长江中 游经济带农产品主产区土地利用转型模式包括 $D_{c}+$ $R_{c}+$ 主导型、 $D_{c}+R_{c}$ 主导型、 $D_{c} R_{c}$ 主导型和 $D_{c} R_{c}+$ 主导型 四种, 其县 (区) 数量分别为 $48 、 17 、 10$ 和 23 个。三 省农产品主产区土地利用转型模式存在明显的差 异性, 湖北以 $D_{c}+R_{c}$ 主导型和 $D_{c}+R_{c}+$ 主导型为主, 湖 南以 $D_{c}+R_{c}+$ 主导型和 $D_{c} R_{c}+$ 主导型为主, 江西以 $D_{c}+$ $R_{c}+$ 主导型为主。从空间分布上来看, $D_{c}+R_{c}$ 主导型主 要分布在襄阳、荆门、荆州、湘潭、抚州等市的县(区); $D_{c}+R_{c}+$ 主导型分布相对分散,主要分布于上饶、赣州、 衡阳、郡阳、咸宁等市的县 (区) $; D_{c} R_{c}$ 主导型和 $D_{c} R_{c}+$ 主导型则形成“吉安-宜春-岳阳-常德-怀化-郡阳永州” 的环状分布 (图 6a)。可见, 长江中游经济带 农产品主产区虽是重要的粮食生产区,但整体而言 其仍需着力提升粮食单产以推动农业现代化发展。

长江中游经济带农产品主产区林地利用转型 方向以 $D_{f}+$ 方向为主, 建设用地利用转型方向以
$D_{u} R_{c}+$ 方向和 $D_{u} R_{u}++$ 方向为主 (图 $6 \mathrm{~b}$ 和图 $6 \mathrm{c}$ )。其中 转型方向为 $D_{u} R_{u}++$ 的农产品主产区主要集中于衡 阳、湘潭等市,转型方向为 $D_{f}$ 的地区零散分布于益阳、 荆州、新余、南昌、上饶、抚州和赣州等市。可见,长 江中游经济带农产品主产区建设用地利用应以控 制规模为主,林地利用应以适度增加规模为主。

(3) 重点生态功能区土地利用转型模式。长江 中游经济带重点生态功能区共计 105 个县 (区), 其 中 92 个县 (区) 的土地利用转型模式为 $D_{f}+$ 主导型, 13 个县 (区) 的转型模式为 $D_{f}$ 主导型 (图 7a)。而在 耕地利用转型方向上, 重点生态功能区以 $D_{c} R_{c}+$ 方 向和 $D_{c}+R_{c}+$ 方向为主, 前者主要集中分布于十堰、 恩施、张家界、湘西、怀化、邵阳、永州、湘州等市, 后 者则主要分布于湖北西南部的“神农架-宜昌-恩 施”地区以及江西九江、赣州和上饶等(图 7b)。分 析可知, 长江中游经济带重点生态功能区耕地粮食 单产较低这一问题突出, 且与 2020 年耕地保有量预 期值相比，恩施、宜昌、神农架、邵阳等市的重点生 态功能区耕地规模潜力仍需进一步挖掘。

长江中游经济带重点生态功能区建设用地转 型方向以 $D_{u} R_{u}+$ 和 $D_{u} R_{u}++$ 方向为主。其中转型方向 为 $D_{u} R_{u}++$ 的地区主要连片分布于西部的“神农架一 恩施-宜昌-张家界-湘西-怀化-邵阳”条带区域, 部 分零散分布于永州、椰州等市的县(区) (图 7c)。
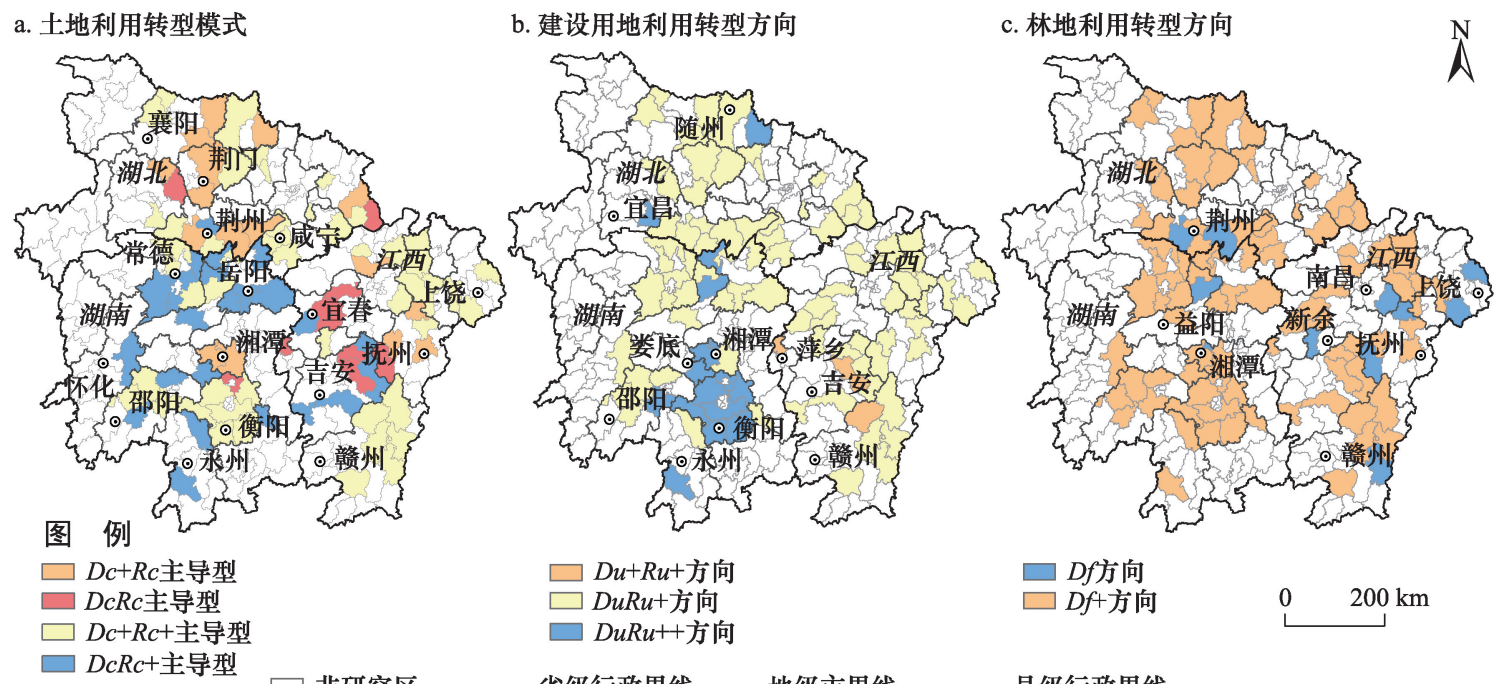

$\square$ 非研究区 一 省级行政界线 一 地级市界线 一 县级行政界线

图 6 长江中游经济带农产品主产区土地利用转型模式及建设用地和林地利用转型方向

Figure 6 The patterns of land use transition and direction of construction land and forest land use transition in the major agricultural production zone in the Middle Reaches of Yangtze River Economic Belt 


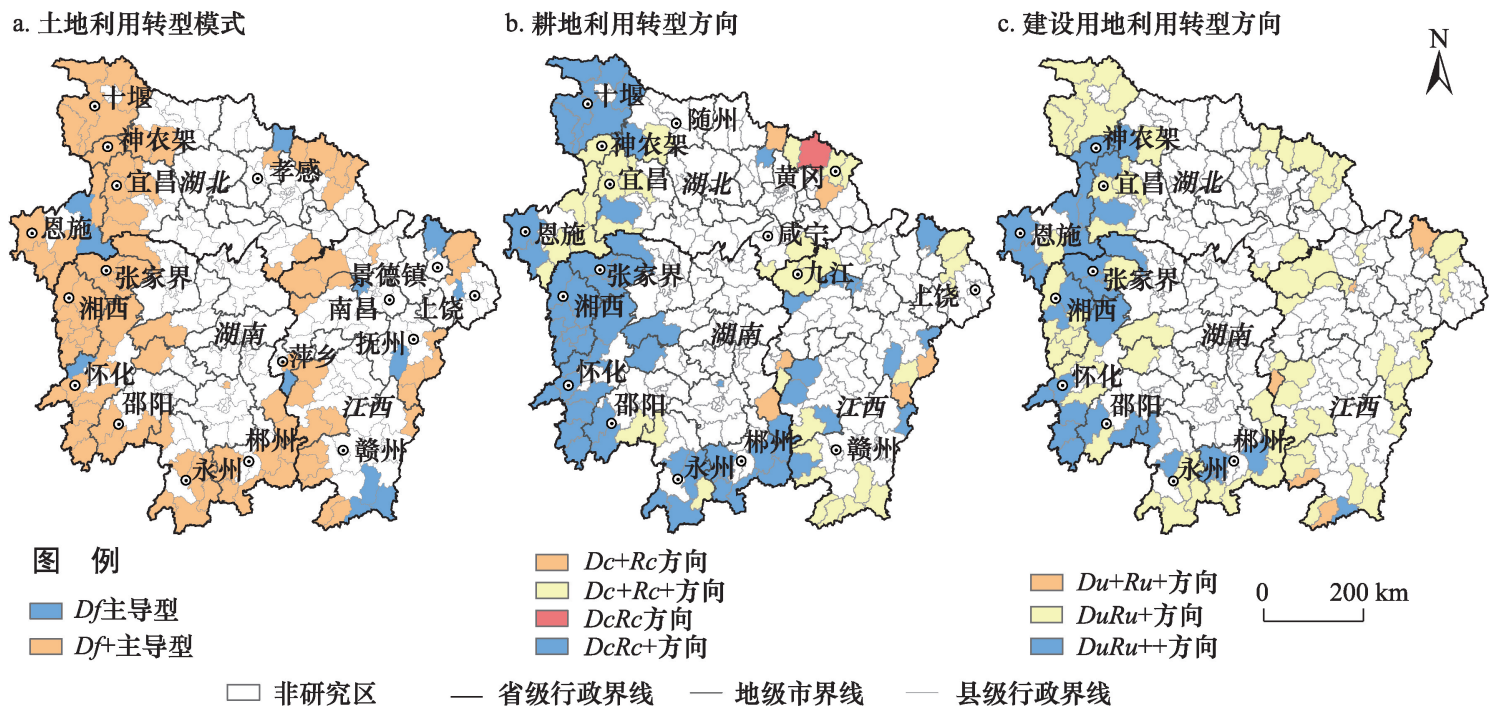

图 7 长江中游经济带重点生态功能区土地利用转型模式及耕地和建设用地利用转型方向

Figure 7 The patterns of land use transition and direction of cultivated land and construction land use transition in the key ecological zone in the Middle Reaches of Yangtze River Economic Belt

\section{5 结论与讨论}

\section{1 结论}

高效的土地利用转型模式是推动区域土地资 源合理配置与利用的有力保障,也是永葆城市发展 动力、激发发展潜力、实现新型城镇化、乡村振兴、 生态文明建设等发展战略的重要推手。为此,本文 从诊断土地利用转型方向人手, 以长江中游经济带 325 个县 (区) 为研究对象, 在深人解析新时期社会 经济转型对区域土地利用转型要求的基础上,尝试 性地提炼了适合各主体功能区的土地利用转型模 式, 得到结论如下:

(1) 长江中游经济带城市化地区土地利用转型 模式以 $D_{u} R_{u}+$ 主导型、 $D_{u}+R_{u}+$ 主导型和 $D_{u} R_{u}++$ 主导 型为主。其中 $D_{u} R_{u}+$ 主导型主要连片聚集于湖北和 江西大多数市域的主城区, $D_{u}+R_{u}+$ 主导型主要分布 武汉、天门、潜江、南昌等的部分县 (区) 且在空间上 多与 $D_{u} R_{u}+$ 主导型片区相邻。 $D_{u} R_{u}++$ 主导型主要分 布于长沙、岳阳等市中经济发展基础较好且城市规 模较大的县 (区) 。 $D_{u}+R_{u}++$ 主导型地区主要零散分 布于长沙、常德和株洲等市中部分城市规模较小的 县 (区) 且多与 $D_{u} R_{u}+$ 主导型区域相邻。此外, 城市 化地区林地利用转型方向以 $D_{f}+$ 方向为主, 耕地利 用转型方向以 $D_{c}+R_{c}$ 方向以及 $D_{c}+R_{c}+$ 方向为主, 且 转型方向为 $D_{c}+R_{c}+$ 的地区主要集中于湖北省。结
合区域特点及其转型模式, 提出建议如下: $D_{u} R_{u}++$ 主导型地区应将提高质量与效益放在首位,着力推 动产业升级以及低效用地的改造, 走建设用地纵深 利用发展之路; $D_{u}+R_{u}++$ 主导型地区应在完善基础 设施的基础上, 强化与周边产业尤其是 $D_{u} R_{u}+$ 主导 型区域之间的联系，同时应加大“城中村”综合整治 力度以提高建设用地利用效率; $D_{u}+R_{u}+$ 主导型地区 应有计划地适度开发建设用地,并借助轨道交通的 发展, 承接其他区域的产业转移; $D_{u} R_{u}+$ 主导型地区 应寻找自身发展的限制因素或短板之处,以“三旧改 造”、“土地整治”等手段推动建设用地“减量化”从 而倒逼城市转型, 同时应寻求新的技术方法与管理 理念, 进一步挖掘建设用地利用潜力。此外, $D_{u} R_{u}+$ 主导型和 $D_{u} R_{u}++$ 主导型地区应重点防治出现掠夺 式开发,并通过开发未利用地、土地复良等措施适 度补充部分耕地和林地。

(2)农产品主产区土地利用转型模式以 $D_{c}+R_{c}+$ 主导型和 $D_{c} R_{c}+$ 主导型为主, 其中 $D_{c}+R_{c}+$ 主导型主 要连片分布于上饶、赣州、衡阳、邵阳、咸宁等市的 部分县 (区), $D_{c} R_{c}+$ 主导型主要零散分布于岳阳、常 德等市的部分县 (区) 。 $D_{c}+R_{c}$ 主导型和 $D_{c} R_{c}$ 主导型 的县(区)较少, 前者主要分布于荆门、荆州等市, 后 者主要分布于宜春、吉安、抚州等市。建设用地利 用转型方向以 $D_{u} R_{u}+$ 和 $D_{u} R_{u}++$ 为主, 前者分布广泛, 
后者主要分布于衡阳、邵阳等市的部分县 (区) 。 $D_{f}+$ 方向为大部分农产品主产区林地利用转型方向。 结合区域特点及其转型模式, 提出建议如下: $D_{c}+R_{c}+$ 主导型地区应严格坚守耕地保护红线, 推动土地整 理复垦, 适度有序地开发耕地后备资源, 同时做好 中低产田改造等工作; $D_{c}+R_{c}$ 主导型地区应重点防治 建设用地占用耕地, 同时鉴于该类型区域耕地资源 分布相对聚集, 可在推动农业规模化经营的同时, 强化耕地利用方向以实现耕地精细化管理; $D_{c} R_{c}$ 主 导型地区应注意警惕耕地低效利用现象,稳定推进 农业现代化; $D_{c} R_{c}+$ 主导型地区应重点加大农业科技 投人,改善耕地利用方式以促进耕地质量与效益提 档升级。此外农产品主产区应抓住当前“农村一二 三产融合”、“精准扶贫”、“美丽乡村建设”等机遇， 主动适应经济发展新常态, 创新发展模式以实现健 康、绿色、和谐发展。

(3) 重点生态功能区土地利用转型模式以 $D_{f}+$ 主导型为主, 比例高达 $87.62 \%$ 。其耕地利用转型方 向以 $D_{c} R_{c}+$ 和 $D_{c}+R_{c}+$ 方向为主, 建设用地利用转型 方向以 $D_{u} R_{u}+$ 和 $D_{u} R_{u}++$ 方向为主。结合区域特点与 转型模式, 提出建议如下: 重点生态功能区一方面 应在大力保护现有林地的基础上,防止毁林开荒等 行为, 并通过植树造林等工程适度增加林地面积; 另一方面, 应结合区域特色, 充分利用自身土地资 源, 依托“精准扶贫”、“全域旅游”等工程, 适度发展 特色农业、生态农业以及生态旅游业等, 提高土地 资源尤其是耕地资源的附加值。

\section{2 讨论}

土地利用转型模式是宏观政策管控、经济发展 需求以及技术水平等多种因素综合作用的结果。 本文甄别了针对一定发展目标下不同主体功能区 土地利用形态变化的典型模式, 可为探究区域社会 经济与土地利用协调发展, 以及各主体功能区协调 发展提供有益参考。同时也应清楚看到, 耕地非农 化、建设用地无序扩张等现实问题是新时代、新发 展阶段中国寻求社会经济生态协调发展必须克服 的困境与瓶颈。粮食安全、耕地保护、生态文明等 战略更是对区域土地资源管理提出更高、更紧迫的 要求。基于土地利用形态转换视角的土地利用转 型模式是社会经济转型背景下土地利用结构和方
式发生变化的综合结果, 研究探测的土地利用转型 模式并将其融人到社会经济转型升级的大框架下 进行考量将为引导未来长江中游经济带各主体功 能区土地资源合理配置与高效利用提供重要依据。

然而,文中土地利用转型目标主要是基于相关 规划需求提出的,鉴于目前中国相关规划多以 2020 年作为规划年, 且新一轮相关规划尚未推出, 为使 转型目标切合实际发展,本研究选取 2020 年作为土 地利用转型目标年展开讨论存在一定的局限。需 要指出的是在提倡社会经济平稳发展的前提下,土 地利用转型模式理应也具有较强的稳定性, 因此在 后续相关规划尚未推出的前提下,可沿此模式将目 标年展望到 2030 年。在新一轮规划推出时,进一步 开展针对更长时间节点 (如 2030 年) 的土地利用转 型模式研究将是后续需要开展的工作。此外, 土地 利用转型作为一定社会经济发展阶段土地利用形 态的动态演变,在某种程度上会受到国家政策等的 影响,加之现有县 (区) 统计资料中部分数据的难获 取性,因此本文提出的土地利用转型模式也许不能 完全反映未来长江中游经济带各主体功能区的土 地利用转型情况,但这是一项探索性工作, 可为后 期相关研究提供参考。

\section{参考文献(References):}

[1] 盛科荣, 謑杰. 主体功能区作为国土开发的基础制度作用[J]. 中 国科学院院刊, 2016, (1): 44-50. [Sheng K R, Fan J. Fundamental institution function of major function oriented zoning for China' s land development and protection[J]. Bulletin of Chinese Academy of Sciences, 2016, (1): 44-50.]

[2] 龙花楼. 论土地利用转型与土地资源管理[J]. 地理研究, 2015 , 34(9): 1607-1618. [Long H L. Land use transition and land management[J]. Geographical Research, 2015, 34(9): 1607-1618.]

[3] 龙花楼. 论土地利用转型与乡村转型发展 [J]. 地理科学进展, 2012, 31(2): 131-138. [Long H L. Land use transition and rural transformation development[J]. Progress in Geography, 2012, 31 (2): 131-138.]

[4] 曲艺, 龙花楼. 基于开发利用与产出视角的区域土地利用隐性 形态综合研究-以黄淮海地区为例[J]. 地理研究, 2017, 36(1): 61-73. [Qu Y, Long H L. The integrated research on regional land use recessive morphology from the perspectives of exploitation and output: the case of Huang-Huai-Hai Region[J]. Geographical Re- 
search, 2017, 36(1): 61-73.]

[5] 曲艺, 龙花楼. 城市土地利用隐性形态空间分异及其影响因素以中国 289 个地级以上城市为例[J. 经济地理, 2016, 36(10): 1-8. [Qu Y, Long H L. Spatial differentiation of the recessive morphology of urban land use and its influential factors: a case study of 289 prefecture-level cities in China[J]. Economic Geography, 2016, 36(10): 1-8.]

[6] Grainger A. The future role of the tropical rain forests in the world forest economy[M]. Oxford: University of Oxford, 1986.

[7] 龙花楼, 李秀涁. 区域土地利用转型分析-以长江沿线样带为例 [J]. 自然资源学报, 2002, 17(2): 144-149. [Long H L, Li X B. Analysis on regional land use transition: a case study in the transect of the Yangtze River[J]. Journal of Natural Resources, 2002, 17(2): 144-149.]

[8] 龙花楼, 李秀彬. 长江沿线样带农村宅基地转型[J]. 地理学报, 2005, 60(2): 179-188. [Long H L, Li X B. Rural housing land transition in the transect of the Yangtze River[J], Acta Geographica Sinica, 2005, 60(2): 179-188.]

[9] 龙花楼. 中国农村宅基地转型的理论与证实[J]. 地理学报, 2006, 61(10): 1093-1100. [Long H L. Rural housing land transition in China: theory and verification[J]. Acta Geographica Sinica, 2006, 61(10): 1093-1100.]

[10] 吕晓, 黄贤金, 张全景. 城乡建设用地转型研究综述[J]. 城市规 划, 2015, 39(4): 105-112. [Lu X, Huang X J, Zhang Q J. A literature review on urban-rural construction land transition[J]. City Planning Review, 2015, 39(4): 105-112.]

[11] 龙花楼. 国内土地利用转型研究的前沿探索[D]. 沈阳:东北大学 出版社, 2016. [Long H L. Frontier exploration of land use transition research in China[D]. Shenyang: Northeastern University Press, 2016.]

[12] 戈大专, 龙花楼, 杨忍. 中国耕地利用转型格局及驱动因素研 究-基于人均耕地面积视角 [J]. 资源科学, 2018, 40(2): 273283. [Ge D Z, Long H L, Yang R. The pattern and mechanism of farmland transition in China from the perspective of per capita farmland area[J]. Resources Science, 2018, 40(2): 273-283.]

[13] 瞿诗进, 胡守庚, 童陆亿, 等. 长江中游经济带城镇建设用地转 型的时空特征[J]. 资源科学, 2017, 39(2): 240-251. [Qu S J, Hu S G, Tong L Y, et al. Spatiotemporal patterns of urban land use transition in the middle Yangtze River Economic Belt[J]. Resources Science, 2017, 39(2): 240-251.]

[14] 刘永强, 龙花楼. 长江中游经济带土地利用转型时空格局及其生 态服务功能影响[J]. 经济地理, 2017, 37(11): 161-170. [Liu Y Q, Long H L. Study on the spatio-temporal patterns of land use transition and its impact on ecological service function of the Middle of Yangtze River Economic Belt[J]. Economic Geography, 2017, 37(11): 161-170.]

[15] 李全峰, 胡守庚, 篗诗进. 1990-2015 年长江中游地区耕地利用 转型时空特征[J]. 地理研究, 2017, 36(8): 1489-1502. [Li Q F, Hu S G, Qu S J. Spatiotemporal characteristics of cultivated land use transition in the Middle Yangtze River from 1990 to 2015[J]. Geographical Research, 2017, 36(8): 1489-1502.]

[16] 程建, 程久苗. 中国省际土地利用隐性形态时空格局、驱动力与
转型模式[J]. 中国土地科学, 2017, 31(12): 60-68. [Cheng J, Cheng J M. The spatio-temporal pattern, driving forces and transformation mode of inter-provincial recessive land use morphology in China[J]. China Land Sciences, 2017, 31(12): 60-68.]

[17] 张佰林, 高江波, 高阳, 等. 中国山区农村土地利用转型解析[J]. 地理学报, 2018, 73(3): 503-517. [Zhang B L, Gao J B, Gao Y, et al. Land use transition of mountainous rural areas in China[J]. Acta Geographica Sinica, 2018, 73(3): 503-517.]

[18] 王福红, 赵锐锋, 张丽华, 等. 黑河中游土地利用转型过程及其 对区域生态质量的影响[J]. 应用生态学报, 2017, 28(12): 40574066. [Wang F H, Zhao R F, Zhang L H, et al. Process of land use transition and its impact on regional ecological quality in the Middle Reaches of Heihe River, China[J]. Chinese Journal of Applied Ecology, 2017, 28(12): 4057-4066.]

[19] 赵丽, 张贵军, 朱永明, 等. 基于土地利用转型的土地多功能转 变与特征分析-以河北省唐县为例[J]. 中国土地科学, 2017, 31 (6): 42-50. [Zhao L, Zhang G J, Zhu Y M, et al. Land multi-functional transformation and characteristic analysis based on land use transition: a case study of Tang county, Hebei Province[J]. China Land Sciences, 2017, 31(6): 42-50.]

[20] Ge D Z, Long H L, Zhang Y N, et al. Farmland transition and its influences on grain production in China[J]. Land Use Policy, 2018, 70: $94-105$

[21] 许凤娇, 吕晓, 陈昌玲. 山东省城乡建设用地转型的时空格局 [J]. 自然资源学报, 2017, 32(9): 1554-1567. [Xu F J, Lu X, Chen C L. Spatial-temporal pattern of urban-rural construction land transition in Shandong Province[J]. Journal of Natural Resources, 2017, 32(9): 1554-1567.]

[22] 郭椿阳, 高建华, 訤鹏飞, 等. 基于格网尺度的永城市土地利用 转型研究与热点探测 [J]. 中国土地科学, 2016, 30(4): 43-51. [Guo C Y, Gao J Y, Fan P F, et al. Land use transition and hotspots detection in Yongcheng city based on the grid scale[J]. China Land Sciences, 2016, 30(4): 43-51.]

[23] Li T T, Long H L, Liu Y Q, et al. Multi-scale analysis of rural housing land transition under China's rapid urbanization: the case of Bohai Rim[J]. Habitat International, 2015, 48: 227-238.

[24] Lambin E F, Meyfroidt P. Land use transitions: socio-ecological feedback versus, socio- economic change[J]. Land Use Policy, 2010, 27(2): 108-118

[25] Liu Y Q, Long H L, Li T T, et al. Land use transitions and their effects on water environment in Huang-Huai-Hai Plain, China[J]. Land Use Policy, 2015, 47: 293-301.

[26] Long H L, Liu Y Q, Hou X G, et al. Effects of land use transitions due to rapid urbanization on ecosystem services: implications for urban planning in the new developing area of China[J]. Habitat International, 2014, 44: 536-544.

[27] Li T T, Long H L, Zhang Y N, et al. Analysis of the spatial mismatch of grain production and farmland resources in China based on the 
potential crop rotation system[J]. Land Use Policy, 2017, 60: 26-36.

[28] 廖柳文, 秦建新, 刘永强, 等. 基于土地利用转型的湖南省生态 弹性研究[J]. 经济地理, 2015, 35(9): 16-23. [Liao L W, Qin J X, Liu Y Q, et al. Study on ecological elasticity of Hunan province based on land use transition[J]. Economic Geography, 2015, 35(9): 16-23.]

[29] 刘永强, 廖柳文, 龙花楼, 等. 土地利用转型的生态系统服务价 值效应分析-以湖南省为例 [J]. 地理研究, 2015, 34(4): 691700. [Liu Y Q, Liao L W, Long H L, et al. Effects of land use transitions on ecosystem services value: a case study of Hunan province[J]. Geographical Research, 2015, 34(4): 691-700.]

[30] Long H L, Tang G P, Li X B, et al. Socio-economic driving forces of land-use change in Kunshan, the Yangtze River Delta economic area of China[J]. Journal of Environmental Management, 2007, 83(3): 351-364.

[31] 刘永强, 龙花楼. 黄淮海平原农区土地利用转型及其动力机制 [J. 地理学报, 2016, 71(4): 666-679. [Liu Y Q, Long H L. Land use transitions and their dynamic mechanism in the Huang-HuaiHai Plain[J]. Acta Geographica Sinica, 2016, 71(4): 666-679.]

[32] 陈龙, 周生路, 周兵兵, 等. 基于主导功能的江苏省土地利用转 型特征与驱动力 $[J]$. 经济地理, 2015, 35(2): 155-162. [Chen L, Zhou S L, Zhou B B, et al. Characteristics and driving forces of regional land use transition based on the leading function classification: a case study of Jiangsu Province[J]. Economic Geography, 2015, 35(2): 155-162.]

[33] Long H L, Qu Y. Land use transitions and land management: a mutual feedback perspective[J]. Land Use Policy, 2018, 74: 111-120.

[34] 宋小青. 论土地利用转型的研究框架[J]. 地理学报, 2017, 72(3): 471-487. [Song X Q. Discussion on land use transition research framework[J]. Acta Geographica Sinica, 2017, 72(3): 471-487.]

[35] 宋小青, 吴志峰, 欧阳竹. 耕地转型的研究路径探讨 [J]. 地理研 究, 2014, 33(3): 403-413. [Song X Q, Wu Z F, Ouyang Z. Route of cultivated land transition research[J]. Geographical Research, 2014, 33(3): 403-413.]

[36] 李志江, 马晓冬, 孙姗姗. 苏北乡村转型与土地利用转型的耦合 分析一以沛县为例 [J]. 江苏师范大学学报(自然科学版), 2015, 33(1): 36-39. [Li Z J, Ma X D, Sun S S. Coupling analysis of rural transformation and land use change in Northern Jiangsu: a case study of Peixian Country[J]. Journal of Jiangsu Normal University (Natural Science Edition), 2015, 33(1): 36-39.]

[37] 龙花楼, 李婷婷. 中国耕地和农村宅基地利用转型耦合分析[J]. 地理学报, 2012, 67(2): 201-210. [Long H L, Li T T. Analysis of the coupling of farmland and rural housing land transition in China [J]. Acta Geographica Sinica, 2012, 67(2): 201-210.]

[38] 蒙吉军, 周平, 艾木人拉, 等. 鄂尔多斯主体功能区划分及其土 地可持续利用模式分析[J]. 资源科学, 2011, 33(9): 1674-1683. [Meng J J, Zhou P, Amrulla, et al. A study on major function-oriented zoning and sustainable land use patterns of Ordos[J]. Resources Science, 2011, 33(9): 1674-1683.]
[39] 韩德军. 基于主体功能区规划的欠发达地区土地利用模式优化 研究[D]. 北京: 中国农业大学, 2014. [Han D J. Optimization of land use patterns of undeveloped areas based on the development priority zones planning[D]. Beijing: China Agricultural University, 2014.]

[40] 刘芳, 张红旗. 我国农产品主产区土地可持续利用评价[J]. 自然 资源学报, 2012, 27(7): 1138-1153. [Liu F, Zhang H Q. Sustainability assessment of land use in main agricultural production regions in China[J]. Journal of Natural Resources, 2012, 27(7): 1138-1153.]

[41] 刹杰, 王亚飞, 陈东, 等. 长江经济带国土空间开发结构解析[J]. 地理科学进展, 2015, 34(11): 1336- 1344. [Fan J, Wang Y F, Chen D, et al. Analysis on the spatial development structure of the Yangtze River Economic Belt[J]. Progress in Geography, 2015, 34 (11): 1336-1344.]

[42] 国务院. 全国主体功能区规划[EB/OL]. (2011-06-08)[2018-0112]. http://www.gov.cn/zwgk/2011- 06/08/content_1879180.htm. [The State Council of China. National Plan for Development Priority Zones[EB/OL]. (2011-06-08)[2018-01-12]. http://www.gov.cn/ zwgk/2011-06/08/content_1879180.htm.]

[43] 中华人民共和国环境保护部. 全国生态功能区划 [EB/OL]. (2008-08-02)[2018-01-25]. http://www.gov.cn/gzdt/2008-08/02/ content_1062543.htm. [Ministry of Environmental Protection of the People's Republic of China. National Ecological Function Division [EB/OL]. (2008-08-02) [2018-01-25]. http://www.gov.cn/ gzdt/2008-08/02/content_1062543.htm.]

[44] 国家统计局. 中国县域统计年鉴(2016)[M]. 北京: 中国统计出版 社, 2016. [National Bureau of Statistics. National Bureau of Statistics. Chinese County Statistical Yearbook in 2016[M]. Beijing: China Statistic Press, 2016.]

[45] 湖北省统计局. 湖北统计年鉴(2016)[M]. 北京: 中国统计出版 社, 2016. [Hubei Bureau of Statistic. Hubei Statistical Yearbook in 2016[M]. Beijing: China Statistic Press, 2016.]

[46] 湖南省统计局. 湖南统计年鉴(2016)[M]. 北京: 中国统计出版 社, 2016. [Hunan Bureau of Statistic. Hunan Statistical Yearbook in 2016[M]. Beijing: China Statistic Press, 2016.]

[47] 江西省统计局. 江西统计年鉴(2016)[M]. 北京: 中国统计出版 社, 2016. [Jiangxi Bureau of Statistic. Jiangxi Statistical Yearbook in 2016[M]. Beijing: China Statistic Press, 2016.]

[48] 湖北省统计局. 各市统计年鉴[EB/OL]. (2016-10-25)[2017-1120]. http://www.stats-hb.gov.cn/info/index.jsp?cat_id=10055. [Hubei Bureau of Statistic. Municipal Statistical Yearbook [EB/OL]. (201610-25)[2017-11-20]. http://www.stats-hb.gov.cn/info/index.jsp? cat_id=10055.]

[49] 北京数字空间科技有限公司. 地理国情监测云平台 [EB/OL]. (2008- 04) [2017- 10- 05]. http://www.dsac.cn/DataProduct/Index/ 200804. [Beijing Digital View Technology Co., Ltd. Geographical Information Monitoring Cloud Platform[EB/OL]. (2008-04)[201710-05]. http://www.dsac.cn/DataProduct/Index/200804.] 
[50] 张红旗, 许尔琪, 朱会义. 中国“三生用地”分类及其空间格局 [J]. 资源科学, 2015, 37(7): 1332-1338. [Zhang H Q, Xu E Q, Zhu H Y. An ecological-living-industrial land classification system and its spatial distribution in China[J] Resources Science, 2015, 37(7): 1332-1338.]

[51] 刘琼, 佴伶俐, 欧名豪, 等. 基于脱钩情景的中国建设用地总量管 控目标分析[J]. 南京农业大学学报(社会科学版), 2014, (2): 80-85. [Liu Q, Nai L L, Ou M H, et al. Analysis on control objective of con- struction land in China based on decoupling scene[J]. Journal of Nanjing Agricultural University (Social Sciences Edition), 2014, (2): 80-85.]

[52] 国务院. 全国农业现代化规划(2016-2020)[EB/OL].(2016-1020) [2017-11-25]. http://www.gov.cn/ zhengce/content/2016-10/ 20/content_5122217.htm. [The State Council of China. National Plan for Agricultural Modernization (2016-2020) [EB/OL]. (201610-20) [2017-11-25]. http://www.gov.cn/zwgk/2011-06/08/content_1879180.htm.]

\title{
The pattern of land use transition in different major function zones in the Middle Reaches of Yangtze River Economic Belt
}

\author{
WU Si, ${ }^{1,2}$, HU Shougeng ${ }^{1,2}$, XIONG Ting $^{1,2}$, ZOU Xiehua ${ }^{2,3}$, ZHU Fan ${ }^{2,3}$ \\ (1. School of Public Administration, China University of Geosciences, Wuhan 430074, China; \\ 2. Key Laboratory of Legal Assessment Project, Ministry of Land and Resources, Wuhan 430074, China; \\ 3. Real Estate Registration Centre, Ministry of Land and Resources, Beijing 100034, China)
}

\begin{abstract}
Under the background of national promotion of ecological civilization construction indepth, with the implementation of the major function zones strategy, the design of the pattern of regional land use transition is significant to solve the conflict between the social economic development and land use in the process of China's rapid urbanization. The current study investigated the Middle Reaches of Yangtze River Economic Belt, with 325 counties selected as a basic research unit, by using the data of Landsat TM images and socioeconomic statistics. From the perspective of land use morphology transformation (the dominant/recessive morphology), the index system of the pattern of land use transition was designed where construction land, cultivated land, and forest land were the typical types. Furthermore, with deeply analyzing the requirements for land use transition in the new age, the transition directions of the three land types were initiated. Finally, following the principles of sustainable development and dominance, our study generalized the patterns of land use transition of different zones. The results indicated that there were four patterns including scale and output capability moderately improved $\left(\left(D_{u}+R_{u}+\right)\right.$-oriented pattern $)$, and scale controlled and output capability moderately enhanced $\left(\left(D_{u} R_{u}+\right)\right.$ - oriented pattern $)$ in the urbanized zone. Four transition patterns including scale increased and output capacity stabilized $\left(\left(D_{c}+R_{c}\right)\right.$-oriented pattern), and scale stabilized and output capacity improved $\left(\left(D_{c} R_{c}+\right)\right.$-oriented pattern) were recognized in the major agricultural production zone, and two transition patterns including scale increased $\left(\left(D_{f}+\right)\right.$-oriented pattern $)$ and scale stabilized $\left(\left(D_{f}\right)\right.$-oriented pattern $)$ were identified in the key ecological zone. The findings of this research will provide a reference for impelling urban-rural composition development in different major function zones in the Middle Reaches of Yangtze River Economic Belt and promote sustainable land use in each unit.
\end{abstract}

Key words: land use transition; pattern; major function zones; the Middle Reaches of Yangtze River Economic Belt 